\title{
BROTHERHOOD IN DISPOSSESSION: State Violence and the Ethics of Expectation in Turkey
}

\author{
KABIR TAMBAR \\ Stanford University \\ (D) http://orcid.org/0000-0003-4724-5489
}

In the summer of 2013, many of Turkey's cities and provinces erupted in protest. Initially sparked by a relatively small demonstration in late May to protect Gezi Park in Istanbul from demolition, the protests grew exponentially in magnitude after police forces aggressively intervened with water cannons, plastic bullets, and tear gas. Confrontations between protesters and the police continued throughout June and into July. The firing of tear-gas canisters alone killed at least two people, one individual was killed with live ammunition, and another died after being severely beaten by a police officer dressed in civilian clothes (Amnesty International 2013). On August 1, 2013, the Turkish Medical Association announced that 5 people had died, 11 had lost an eye, 106 had suffered serious head injuries, and 63 were in critical condition (Türk Tabipleri Birliği 2013).

In late June of that year, as much of the country was convulsing with these events, Selahattin Demirtaş, the co-chairman of the pro-Kurdish Peace and Democracy Party, addressed members of his party. He began not with the Gezi events but with bombings that had taken place in Roboski village in the province of Şırnak in December 2011. Two Turkish fighter jets had fired at and killed what the government claimed were militants of the Kurdistan Workers' Party (PKK) crossing the Turkish-Iraqi border. ${ }^{1}$ It turned out that the thirty-four individuals killed were civilians, not guerrillas. They were smuggling goods, such as cigarettes, tea, and oil, and it appears that security forces were in fact well aware of 
these circuits of trade. Despite major protests that occurred after this incident throughout many Kurdish-majority cities in the southeast of Turkey, the official investigation did not lead to the prosecution of the guilty parties.

About ten minutes into his discussion, Demirtaş (2013) indicated that this sort of state violence did not only apply to Kurds. Asking his audience to consider the ongoing protests in Istanbul and elsewhere, he continued: "When looking from Gezi Park . . . Roboski is more easily understood.” For Demirtaş, many of those looking from the debris of Gezi's barricades were members of the Turkish majority who might not have previously viewed state violence in the Kurdish provinces with much sympathy or comprehension. ${ }^{2}$ To look from Gezi, in the assessment of Demirtaş, was to be granted the opportunity for historical insight. Demirtaş was not only alluding to recent historical events or to violence against Kurds; he proceeded to mention the Armenian genocide of the early twentieth century and episodes of violence against Alevis in the 1930s, 1970s, and 1990s. The experience of police aggression in Gezi offered its participants an unmasked look at the violent underbelly of republican statecraft.

Demirtaş did not shy away from supporting the protesters and critiquing the government's intransigent recourse to police violence in the face of dissent. However, in situating this violence within a longer history, his speech worked against efforts to celebrate the protests as spontaneous and novel, and he refused to identify the violence on display as a scandalous departure from the historical ideals of the republic. The scandal of state aggression against select members of its citizenry betrayed an all-too-familiar political form that repeated itself throughout republican history. Rather than simply denounce state violence in Gezi Park, Demirtaş pointed to its generative possibilities. He concluded his history of violence with a gesture toward a possible political future: "Confronting all of these facts [of historical violence], confronting these truths, is an opportunity. It's an opportunity to better understand one another."

I will return to Demirtaş's speech later in this essay; along the way I will discuss other discursive events that also sought to recast the historical significance and generative potential of the violence that dominated the protests. What interests me is less the constructed nature of historical narrative- a point long stressed by many scholars of nationalism - and more the way in which appeals to history act as interventions into imagined futures. As public statements, these contentious histories constitute acts of address that seek to provoke and discomfit those in their audiences who have benefited from the forms of state repression now called into question. These historical discourses not only challenge official 
narratives of state formation; they also call on those who have been interpellated by official history to question the violence that has informed their own investment in a political future secured by the state.

To understand the relationship between historical pasts and political futures, I find it helpful to draw on Reinhart Koselleck's (2004, 259) distinction between the space of experience and the horizon of expectation. These categories are meant to conceptualize the sinews that bind memory to anticipation. Experience is "present past, whose events have been incorporated and can be remembered." Expectation, by contrast, is "future made present . . . [directed] to the not-yet . . . to that which is to be revealed." Both of these terms, experience and expectation, are open to rival figurations. As anthropologists attuned to the temporal tropes of modernization have insisted, expectations are themselves both objects of political control and vulnerable to historical revision, open to competing social claims (Ferguson 1999; Coronil 2011; Piot 2010; Bryant 2012).

The moments depicted here sought to rearticulate past to future in ways that both exemplified the broader spirit of state critique animating the Gezi protests and that tried to establish distance from them. This estranged engagement might be understood as the tense, dialectical act of leveraging, from within the very terms that structure political life, a reflexive interrogation of its organizing categories. The commentaries I discuss in this essay revisit the history of state violence against populations labeled as minorities or threatened with that designation; at the same time, they position their own discourse as addressed to the putative majority, or those who would identify as such. What results is not primarily a set of claims to rights, resources, or recognition that presupposes the state as the site of political adjudication. Rather, the encounter yields an ethical demand on the would-be majority to recognize the histories of violence that have constituted its own sense of political identity. This essay unpacks that ethical demand.

I follow recent anthropological studies of ethics in emphasizing that any effort to step back from and reflexively evaluate social practice is a historically constituted practice in its own right, one that can be directed toward the task of transforming a subject's sensibilities and dispositions (Zigon 2007; Faubion 2011; Laidlaw 2014; Keane 2014). Traditions of ethical self-scrutiny are often most clearly defined in contexts of disciplined pedagogical authority, under the tutelage of moral guides or exemplars (Robbins 2004; Mahmood 2005). The moments I describe in this essay are ones in which a community of actors invites its addressee (the majority) to inaugurate a process of self-transformation and to disidentify 
from categories in which it is currently invested. However, the self-transformation in question is demanded not by a recognized authority, but by those who have been historically dispossessed, and it is addressed not to subordinates but to those who have enjoyed political privilege. My analysis explores a form of address in which those issuing the demand for transformation have lacked the authority to set the terms of speech, and where the historical privilege of the addressee manifests above all in the ability to refuse to recognize that a dialogue is even being initiated. Indeed, the inability to enjoin a response from a reticent addressee is not necessarily a product of individual communicative misfires; in the cases under study in this essay, it is a structural effect of what scholars have more generally understood as the state's symbolic and affective regulation of public life (NavaroYashin 2002; Cody 2011; Mazzarella 2013).

The ethical mandate I am examining arises in forms of public speech that seek to reorient the conditions of the speech setting itself or what, following Charlene Makley (2015, 454), we might term the conditions of "mediated addressivity" (see also Bakhtin 1986). The actors discussed in this essay are attempting to establish lines of communication that, while neither indifferent to nor satirical of the state's dispensation of politics (cf. Yurchak 2008; Haugerud 2012; Boyer 2013), nonetheless contravene its structuring conventions, even reversing its normative valences. In doing so, they challenge those who have historically benefited from the state's governing rationalities to identify with populations that these same administrative logics have externalized as foreigners or criminalized as terrorists. With the aim of elaborating a highly charged modality of intercommunal ethics, my account pivots around certain types of ethnographic material: moral appeals that, through both admonishment and entreaty, endeavor to transform the conditions in which the claims of the speaker might be heard by his or her interlocutor.

This essay, then, suggests that anthropologists would do well to interrogate the medium of speech and address that gives voice to the critique of violence. As a social practice, the act of criticism presupposes contexts and relations of address that are themselves products of the history of unequal power relations scrutinized by the critic (Tambar 2012; Muir 2015). The ethical force of these speech acts resides in the way they unsettle the institutional conditions of the dialogue they are attempting to commence. These dynamics are paradoxical, though productively so. They enable an ethics of expectation in which the impasses of address and nonresponse become so many indexes of a future not yet realized. 
Throughout the essay, I speak of a would-be or putative majority to stress that it is a category of aspiration, rather than simply an empirical designation. The term Türk shelters a linguistic ambiguity between ethnic identity and legal citizenship (Bayır 2013). This ambiguity is itself symptomatic of a historical conflation of the demographic concept of majority, which is an ostensibly measurable quantity of population, with the normative concept of nation, which purports to unify political community in the state. The efforts by Demirtaş and others whom I discuss in this essay to address the majority are precisely aimed at prying open this gap, disinterring the demographic from its normative cast to reorient its horizon of expectation.

I begin by exploring how the category of minority has helped scaffold the normative subject of political modernity, the nation. The figure of the minority has been shaped by what I call a negative historicity: negative in the sense of being evacuated from the time and place of historical progression that has characterized the national subject. The symbolic space of national sovereignty, as it came to be defined with the birth of an international order of nation-states following World War I, renders the minority spatially displaced - seen as foreign to what may have constituted its historical homelands - and temporally suspended from the narrative tethering of national experience to expectation.

After fleshing out the negative historicity of the minority, I return to scenes of commentary adjacent to the Gezi protests, asking how their temporal interventions redirect the minority question toward an ethical inquiry into the aspiration to majority. Rather than rejecting the temporal suspension of the minority from the historical narratives of the Turkish nation, Demirtaş and others deploying this discursive maneuver summon Gezi protesters to relinquish their own sense of progressive historicity and, in effect, to embrace the negative historicity so often ascribed to the objects of state violence. They seek not so much to redeem the nation from the violence it has unleashed, as to ask whether that very violence might serve as the ground on which to produce an alternate figure of a political community to come.

\section{THE MINORITY QUESTION}

The minority question defined the founding of the Turkish Republic in 1923. I do not simply mean that, as with any nation-state, early republican leaders strove to standardize language, history, and cultural heritage in such a way as to marginalize religious and ethnic minorities. That broadly modular process was given sharper definition by the peace settlements that concluded World War I (between 
1919 and 1923) and led to the emergence of the Turkish Republic. The historian Eric Weitz (2008) notes that these settlements were premised on a new conception of politics, one focused on discrete populations and the ideal of national homogeneity. He provocatively argues that this conviction enabled two seemingly contrary historical results: on the one hand, a new concern for the legal protection of minorities and, on the other hand, internationally sanctioned, forced deportations of populations from their historical homelands to new nation-states where they were now said to more authentically belong. According to Weitz, the new protections for minorities did not simply constitute a humanitarian response meant to safeguard those communities from oppressive majorities. A certain violence also formed part of those protections and of that new concern for the minority.

The formation of the Turkish state exemplifies the conundrum of minority protection and displacement at the heart of the postwar global order. From the republic's foundation in 1923, Jews, Armenian Christians, and Greek Christians were recognized as minorities and offered legal protections with regard to the autonomy of their religious organization. And yet, in the years leading up to the formation of the republican state, Armenian communities were deported or exiled from Anatolia and killed, and the Lausanne Treaty that promised minority recognition also led to the so-called population exchanges that compelled many Orthodox Greeks to leave Turkey. The category of minority came to index a process of dispossession - from rights to land, from political status, and from a sense of belonging.

In this context, a community recognized as a minority gained certain rights and protections from the state. However, this recognition also carried the weight of an extraordinary historical judgment, one that inheres in what I am calling negative historicity. At once moral and political, the negative historicity of the minority implied that the community in question was in some sense external to the nation and its history, external to the body politic, and so also of suspect loyalty, even in cases where the so-called minority population had deep historical roots in the territory now dominated by the new nation-state. Recognized as a population within the citizenry but distinct from the presumed majority, the minority constituted a figure at once included in and excluded from the biopolitics of the nation-state. If sovereignty in the republican state was constitutionally vested in the nation, those now classed as minorities would always remain ambiguously connected to this project. They were legally recognized as citizens and yet treated as suspect others. As Aron Rodrigue $(2013,44)$ argues, those classed as minorities "could remain Turkish citizens, but they would never be true Turks." 
The ethos of suspicion was amplified by the fact that leaders of the new Turkish republic came to view the very designation of minority as a symbol of Western imperial ambitions: in demanding that the minority clauses be accepted by the new republic, Western powers encroached on the nation-state's sovereign autonomy in the very act of recognizing it (Ekmekçioğlu 2014).

Mark Mazower (1997) argues that after World War II, Western powers shifted their emphasis from collective rights to individual human rights. Yet this change in ideological accent did not lessen the stigma attached to minorities. To consider some paradigmatic examples from the mid-twentieth century, the construction of Arabs as a minority in Israel and of Muslims as a minority in India were broadly comparable to the process that shaped dominant forms of political subjectivity and state identity in Turkey several decades earlier. The histories of state formation in Israel and India were, in many respects, quite distinct: India was founded through anticolonial struggle and partitioned at the moment of independence; Israel was established through settler-colonial practices and, despite U.N.-led plans for partition, never separated into two states. In each case, however, a normative narrative of national belonging was fostered through the forced expulsion and dispossession of many of those now recognized as a minority, and those among the minority who remained had to bear the burden of proving loyalty to state authorities who viewed them as foreign (Pandey 1999; Robinson 2013). Compare also the case of Copts in present-day Egypt: intellectuals and organizations within the community continue to debate the risks of pursuing rights as a religious minority, because such a designation might mean their exclusion from statist narratives of national unity (Mahmood 2012).

The term minority (azınlık) in Turkey today functions more often as an accusation hurled at socially vulnerable populations than as a strictly legal-bureaucratic category for allocating resources or ensuring communal rights. It is in this context that the Jewish community, historically recognized as a minority, has anxiously debated the safety of publicly displaying religious signs, for fear of being accused of disloyalty to the state (Brink-Danan 2011). Other marginalized groups who are not recognized as minorities are nonetheless not simply accepted as part of the majority; as a result, they frequently make strident appeals to the dominant ethnoreligious imaginaries of the nation. Undocumented Bulgarian migrants, working under conditions of legal constraint and social precarity, have sought avenues of limited political inclusion by claiming ethnoreligious identification with the Turkish majority (Parla 2011). Some Turkish converts to evangelical Christianity, who remain largely unconstrained by the legal limits faced by undocu- 
mented migrants but who often suffer harassment and violence, also seek majority status. They socially distance themselves from the Armenian and Greek Orthodox Christian churches, which were labeled as minorities after Lausanne, in efforts to present themselves as authentically Turkish (Özyürek 2009). Alevi civil society groups have waged struggles for collective rights that are in fact offered to recognized minorities, like exemption from state-mandated religion courses in elementary and secondary schools, but they have overwhelmingly rejected overtures from the European Union to claim such rights under the minority designation. They justify their repudiation of the term with the claim that they are foundational elements (asli unsur) of the Turkish state (Tambar 2014).

These examples indicate that what appears to be a simple binary of majorityminority in fact orients a heterogeneous field of unequally positioned identities and claims. Importantly, these examples also exhibit a shared underlying assumption that the category of minority functions not only or even primarily as legal protection; it operates more potently as a mode of social recognition that groups seek to evade, protect themselves against, or overtly repudiate, because it threatens to excise the community in question from the historical past and future of the nation and its purportedly unified people.

For their part, Kurds have long been viewed by Turkish state elites as "prospective Turks" (Yeğen 2007) — that is, because of their predominantly Muslim denominational affiliation, they have often been seen as assimilable to the social, linguistic, and political norms of belonging in the Turkish nation. In moments when Kurdish organizations have been perceived as raising a fundamental threat to the Turkish state, especially acute in the past few decades with the onset of armed confrontation between the state and the PKK, Kurdish political leaders or public figures have faced accusations not simply of committing legal crimes but of being crypto-Jewish or crypto-Armenian — ethnoreligious affiliations whose minority associations mark them almost self-evidently as treasonous (Yeğen 2007; Paker 2010). Applicable even to those once considered prospective Turks, the negative historicity of the minority entails a moral sensibility that sustains ideological exclusions and justifies collective violence.

It is worth noting that the Justice and Development Party (AKP), which has established a dominant position within the Turkish government over the past decade, describes its own history as a struggle against state repression. The leader of the party and prime minister at the time of the protests, Recep Tayyip Erdoğan, commonly asserts that his party represents the oppressed (ezilen) who have not only been neglected but also actively marginalized by Kemalist elites. The AKP 
does not, however, define its constituency as a minority (azınlık). To the contrary, it sees itself as the authentic representative of the nation. ${ }^{3}$ Prime Minister Erdoğan explicitly asserted this claim during the Gezi protests. Seeking to counter the globally circulating images of popular discontent, he organized a mass gathering of his own under the heading "A Meeting That Respects the National Will." In his speech, Erdoğan mentioned the military interventions that led to the execution of Prime Minister Adnan Menderes in 1961 and the banning of the Islamist Welfare Party in the late 1990s. Politicians from the AKP often reference these events as exemplifying state oppression against the line of parties and organizations from which their own party derives. Erdoğan went on to proclaim that, on each occasion, the nation (millet) responded at the ballot box (Sabah 2013). The AKP's invocation of a history of state violence contributes to its own rendering of the national subject. We will have to look elsewhere for a frontal interrogation and productive repurposing of the minority's negative historicity.

\section{FINDING AN INTERLOCUTOR}

Every week, a group called the Saturday Mothers/Peoples (Cumartesi Anneleri/insanları) hosts a public vigil to remember individuals who were forcibly detained by security forces, disappeared, and are now presumed dead. Many of the disappearances occurred in the 1980s and 1990s in the predominantly Kurdish provinces of the southeast, and so the group speaks from a similar history of violence that provided a context for Demirtaş's speech described above. In most cases, neither have the bones of the dead been returned to their families, nor have the perpetrators been brought to justice. ${ }^{4}$ Participants in these gatherings include mothers and other relatives of the disappeared, friends, and other supporters, including lawyers working for the Human Rights Association (Insan Hakları Derneği). Most participants, whether Kurdish or Turkish, have never been formally classed as minority in Turkey, but in drawing attention to the systematic nature of what might otherwise appear an aberrant practice of enforced disappearance, the Saturday Mothers and their supporters have struggled to expose and stage for public display the biopolitical liminality more commonly associated with minorities (Bargu 2014).

The group started to hold these weekly gatherings in 1995 and eventually stopped in 1999 because of repressive police force. They resumed them again in 2009, and while their gatherings these days by and large do not incur state intervention, police forces invariably arrive prior to their public rallies and make their presence felt by standing about a hundred yards away. Thus, the Mothers' 
activities have been shaped by a history of police violence and surveillance, long prior to the Gezi events. In Istanbul, they gather on Istiklal Avenue, the central pedestrian thoroughfare where the Gezi protesters were also active. ${ }^{5}$

At these events, participants commonly talk about relatives and friends who were forcibly disappeared, but during the summer of 2013, they connected these histories of detention and disappearance to the authorizing of police violence during the Gezi events. In reference to the latter, one participant said: "The scenario hasn't changed; only the players have changed.”

Another participant commented on the fact that the prime minister had recently made a speech in a Kurdish-majority province about the peace process that the ruling government was pursuing with the PKK. In that speech, Prime Minister Erdoğan had reportedly announced: "Spring has come to the mountains and mothers will no longer cry." The speaker at the Saturday Mothers event responded by saying that in only one month, the police had killed five young people. "Are their mothers not really mothers?" he asked. The speaker here again articulated the Gezi events to a longer history of state violence, identifying continuities with an earlier era of state power that the ruling government often claims to have superseded and left behind.

Following one of the Mothers' events in July 2013, I found the opportunity to ask one of the founding members of the group about the current protests. Her brother had been detained and killed by police forces in 1995, and her family had been among the first to begin publicly gathering in protest of the disappearances. I asked her why speakers at these events persistently made reference to the Gezi protests. She responded that both cases - enforced disappearances and the current clashes between protesters and the police - involved the same phenomenon: state terror (devlet terörü). The discussion continued, as it often does, at a crowded tea garden tucked away on a passageway that extends from the main avenue. Another regular participant in the vigils, whose brother had also been forcibly disappeared in 1995, indicated why the group sympathized with the current protesters: as a group that has known state violence intimately, he explained, they were calling for an end to the recent acts of police brutality.

This was not the first time the Saturday Mothers had acted in solidarity with a movement dedicated to protesting state violence, especially violence against minorities. Some members of the group reported to me that they had joined annual demonstrations to commemorate and mourn the assassination of Hrant Dink, an Armenian intellectual who had been prosecuted several times for "denigrating Turkishness" and who was gunned down in 2007 by a right-wing nation- 
alist, Ogün Samast. Photographs of Samast in custody, flanked by police officers proudly waving a Turkish flag, demonstrated to many critics that at least some members of the police supported the killer; police officers working in intelligence units have since been arrested as part of the official investigation into the murder. The connection drawn by the Mothers between these different episodes, linked by the rubric of state terror, exposes a form of officially sanctioned violence against communities whose loyalty and obedience state authorities doubt.

The historical sensibility evinced in the Saturday Mothers' gatherings in 2013 was apparent not only in their comments on state violence and its precedents in the Kurdish southeast, but also in a number of comments focused on the gatherings themselves and the mode of address they have been developing for the past twenty years. One participant exclaimed that they have been coming to this location for a long time and that only now, with the Gezi protests, they were discovering to whom they had been speaking all this time. In a more muted tone, an elderly mother asked: "Why have we been sitting here? No one has heard our voice. People come and go [past us], but without hearing our voice, and nothing has been done." Pressing the point further, she later merged her concerns about enforced disappearances in the Kurdish southeast with the Gezi protests: "What happened in Gezi Park? They were sitting in the shade over there. What was over there, was it a war? We say to everyone: Listen to our voices. End this war. Let mothers laugh a little." In her statement, the term war references both the three-decade armed conflict between the Turkish state and the PKK and the excessive response of the police to protesters in the park.

Undoubtedly, as with any act of public address, the speech act is heard and taken up by a range of differently positioned actors. In many respects, the Mothers' voices have reverberated more strongly in international settings than in domestic ones: Amnesty International organized sit-ins in Paris, Berlin, Sydney, and London to support the gatherings in Istanbul; the International Human Rights Association awarded the Mothers the Carl von Ossietzky Prize; and they were the subject of a documentary by a French filmmaker (Baydar and Ivegen 2006, 696-97). It is nonetheless striking that many in the group, when speaking about their reception in the domestic arena, claim not to have been heard. They indicate that the communicative setting that their vigils presuppose has by and large not been recognized by their presumed addressees in the mainstream Turkish public.

The issue is not only that they have struggled to motivate legislators to reform criminal law or to inspire public prosecutors to raise cases against state officials. Beyond this legal impasse, they point to the fact that members of the 
putative Turkish majority have largely failed to respond to the ethical claims that the Mothers have sought to make on them. Their acts of address, iterated across years of weekly speech acts, carry the burden of creating a context of interlocution that their intended addressees have refused to recognize. The speech act presupposes a context of communication it must in fact produce. This paradox of performativity, I suggest, is not simply stifling; it produces an ethical charge that enables a sense of expectation. The ethical impetus derives from the gap between the communicative impasses the Mothers have persistently confronted and a dialogical encounter they posit as a possible future.

To draw out this argument, it is helpful to note that scholars who have examined the Saturday Mothers have broached questions concerning the ethics of the group's public presence largely by analyzing the gendered politics of motherhood. If some have argued that the group "revolutionizes the traditional maternal role" (Arat 1999, 376), others have worried that the moral resonance of motherhood risks depoliticizing the gatherings (Baydar and İvegen 2006). The idea of mothers-in-mourning seems to domesticate, within traditional gender relations, what might otherwise be taken as a deeply political protest against the violent abuses of state power. State authorities themselves appear vexed by this performance of mourning, adopting conflicting positions on its legitimacy. At certain moments, they have permitted the Mothers to convene in public with little harassment. At other times, police forces have aggressively intervened, even attacking members of the group, and on occasion detaining some participants on charges of aiding terrorism. ${ }^{6}$ Ignored and harassed, permitted and repressed, the gatherings prove unsettling for state authorities and much of the mainstream Turkish public.

The tensions elicited by the Mothers at least in part result from how the Turkish state has invested in the morality of motherhood. The militarized masculinity of Turkish nationalism has presupposed a feminine counterpart, whether in the form of daughters, capable in some cases of participation in the military, or, more commonly, in the form of mothers, who support and "reproduce" the military nation (Altınay 2004). The recursive loop that links the morality of motherhood to the politics of national sovereignty was reactivated in the $1990 \mathrm{~s}$ when Turkish media outlets began to report on a group of Turkish mothers who met in a cemetery on Fridays to collectively mourn the deaths of sons who, as Turkish soldiers, died as "martyrs" in the armed conflict with the PKK. Zeynep Gülru Göker (2011a, 170) notes that in nationalist media portrayals, the "mothers 
of the martyred" were explicitly set in contrast with the Saturday Mothers, in effect constructing a "hierarchy of grief."

The Saturday Mothers invoke recognizable tropes of motherhood — of an emotional, moral obligation toward sons - and yet repudiate militarism's gendered narrative of national reproduction. Their public vigils appear uncannyfamiliar yet alien - to many in the Turkish public, including state authorities, because they rely on what is conventional in them: the dissident demanding that state officials be brought to justice is at the same moment a mother calling for public acknowledgment of her moral claim to mourn her child's death. ${ }^{7}$

The Saturday Mothers hold out an ethical provocation to those who would identify with the Turkish majority - a provocation to which, according to some in the group, few within that majority have been willing to rise: to recognize the moral claim of the Mothers' mourning and, in doing so, to denounce the violence of the state that acts in the majority's name. If many in the Mothers group have worried about the absence of an interlocutor, the issue only in part concerns the way in which state authorities and media outlets have censored or silenced their voices. More significantly, they are suggesting that the would-be majority can only become their addressee, responsive to their moral claims, if that majority embarks on a process of self-transformation.

The statement mentioned above, that the Mothers are just now finding an addressee, indicates that some within the majority are beginning to constitute themselves as interlocutors for the Mothers' claims, but only after having confronted police violence in the Gezi protests. The Mothers' practices of historical analogy open an explosive ethical question: what encounters with the state's security battalions would the putative majority need to endure, and thus what would that majority need to become, to see the decades-old struggle of the Saturday Mothers as part of its own political experience, formative of an expectation to come?

\section{FROM MINORITY TO MAJORITY}

As the Gezi protests unfolded, there was considerable commentary in Turkish news outlets and blogs about the extent of Kurdish involvement. Some protesters, who have seen Kurds rise up en masse to oppose state violence on countless previous occasions, were frustrated that Kurdish cities had not displayed the bold street politics for which they are often known. Many participants with whom I spoke during the protests complained that Kurdish politicians were too ambiguous in their support. ${ }^{8}$ 
Selahattin Demirtaş was not dismissive of the Gezi uprising, but he did not celebrate it either. Rather than addressing the question of why Kurds were not more forcefully joining the protests, he reversed the frame, stressing that Turks were only now seeing what their state was capable of doing to its own citizens and that they were only now experiencing a historical reality that Kurds had long known. This stance and the distance from the protest that it implied made for objects of considerable critique among Gezi activists. Several Turkish protesters, a few of whom were longtime supporters of the Kemalist Republican People's Party, described this distance to me with some bitterness. They explained that Demirtaş and the Kurdish political party he represented were involved in the peace process that the ruling government was negotiating with the PKK, and that the party did not want to upset that process by openly participating in the Gezi uprising. These protesters maintained that Kurdish politicians, who had long struggled against state authoritarianism, were now allowing realpolitik to blunt any support they might give to an antiauthoritarian protest movement.

Such explanations of political maneuver are plausible, but they underestimate the social significance of this hesitancy among many Kurds. It is important to recognize that this critical distance from the protests, accompanied by the historical sensibility that Turkish protesters were only beginning to witness forms of violence previously applied against Kurds, was not only a matter of tactical cunning on the part of a political party. It resonated with sentiments that I encountered in the course of fieldwork in Diyarbakır (a key cultural and political center of the Kurdish movement in Turkey) with Kurds hailing from a range of age cohorts and class backgrounds.

I asked a lawyer in his mid-twenties to explain the political significance of the Gezi protests, but rather than engage the question, he smirked dismissively, adding only that Turks in the western provinces of the country were just starting to grapple with issues that Kurds in the east had faced under more dire circumstances for decades. Welat, a retired man in his late sixties living in a workingclass neighborhood of Diyarbakır, was less cynical in his assessment, asserting that people in his city supported the Gezi protesters. Yet he proceeded to list many of the Kurdish politicians from his neighborhood alone who had been arrested by the Turkish state during the past few decades, indicating that the history of oppression against Kurds has been ongoing for thirty to forty years. The judgment of Delal, a middle-aged woman who worked for the city's municipal government, was more attuned to the mediatized nature of the Gezi protests. She said that audiences in Europe and North America were gripped by videos of police violence 
against Gezi protesters, but that photographs of the injured and dead in Turkey's Kurdish-majority cities have never been permitted to circulate so widely, nor have they been viewed with such sympathy. ${ }^{9}$

Demirtaş's (2013) speech was grounded in and emerged from this social milieu. It is worth examining the speech in more depth because Demirtaş gave voice to popular sentiments in the form of an address, turning the hesitancy felt by many Kurds into an ethical demand on the would-be majority. It resembled, even if it was not altogether identical with, the discourse of the Saturday Mothers. While Demirtaş did not appeal to tropes of motherhood, he made recourse to a history of violence to recast the space of experience out of which the current conflagration around Gezi Park emerged. Recall that he began by describing the bombing in Roboski village, framing that event as a precedent to the more recent acts of state violence against Gezi protesters. What makes this framing more combative is the way that it serves to ground a horizon of expectation. The contentious character of this narrative tethering of memory to anticipation became apparent in the course of the speech, as Demirtaş's tone shifted from historical description to moral admonishment. This shift was marked grammatically, as Demirtaş began to directly address his audience in the second person:

As with groups in power in the past, the habit of lying that we find in this [governing] power has a counterpart among the people. . . . I wish to remind especially those who support the prime minister and nourish his lies. . . . He lied that "the BDP [Demirtaş's political party] coercively gathers votes" . . . that "it pays children to throw stones," and you believed it [siz inandınız]. . . . He said that during the hunger strike [among Kurdish prisoners in 2012], "they are eating inside." You believed it [siz inandınız] . . . . He lied in Roboski, you believed it [inandinız]. . . . Now it's emerged that he lied that [Gezi protesters] were drinking alcohol in a mosque [where they were given shelter and medical care], and as if this was the first time he's lied, you started to raise objections.

The repetition of the phrase you believed it functions poetically, in Roman Jakobson's $(1960,369)$ sense: the rhythmical and patterned parallelism fosters "interaction between meter and meaning." Concentrating attention on itself, the phrase builds in importance, even as it rests on the denotationally unspecified deictic "you." To whom is Demirtaş directing this reprimand? 
At the start, it is clear that Demirtaş (2013) is talking about supporters of the prime minister and his political party. Yet as he continues, the you he is challenging assumes greater proportions.

Will you still believe the lie that "Armenians went around from one place to another, sometimes along the way, because of some problems, a few people were killed?" Or will you hear the truth that they suffered an officially [organized] genocide, they were officially eliminated? Alevis in Dersim, Maraş, Çorum, Sivas, Gazi were killed at the hand of official state policy. Will you now believe this truth?

The events he mentions - the Armenian genocide of the early twentieth century and violence against Alevis in the 1930s, 1970s, and 1990s - all preceded the rise of the AKP-led ruling government. They involved a constellation of state authorities and political parties that embraces much of the field of mainstream politics, across a landscape of political groups that otherwise claim to oppose one another. When Demirtaş alludes to "lies," he claims to be describing official state policy, the same policy that has been part of the ascription of negative historicity to the minority. Turkey's current government, on this account, is not the originator of those lies but has continued the tradition of adhering to them. For Demirtaş, the elision of these events of historical violence in public memory has been supported or tacitly accepted by secularists as much as Islamists, by rightwing nationalists as much as left-leaning liberals.

Demirtaş's account brings together events of violence that took place at different historical moments and, arguably, it risks flattening into a single narrative modalities of violence that are worth distinguishing — violences of different scale and acts of state repression with different mechanisms and consequences. What interests me here, however, is not simply the historiographical validity of his narrative (for instance, whether the episodes of violence against Armenians, Alevis, Kurds, and Gezi protesters constitute a single continuous history or a more heterogeneous set of agencies, interests, and effects). In line with the argumentative thrust of this essay, I want to suggest that his effort to consider these events together produces an ethical demand worth taking seriously in its own right.

Demirtaş's admonishment extended not only to the AKP's electoral base but even to some of those involved in the protests, including Kemalists and other nationalists. What is striking about the ambiguity of the "you" in Demirtaş's address is the lack of strong distinction between Kemalists and Islamists - the "white Turks" that long dominated Turkish politics and the "black Turks" that 
have come to power in their stead in recent decades (on the political significance of these categories, see White 2013, 46-48). This seemingly commonsense distinction of contemporary Turkish politics holds no salience here and is actively destabilized. When he says "you believed it," the you includes anyone who identifies with a national horizon of expectation without interrogating the experiences of violence that have produced it.

These events of violence were foundational to the history of the body politic. The violence against Armenians mentioned in the speech occurred in the waning years of the empire, in the very years when imperial elites feverishly adopted ethnic nationalism, which proved consequential in entrenching the ideological terms of nation-state formation in the following years. The episodes of violence targeting Alevis that Demirtaş mentions took place later, but in the speech itself, he invokes a string of cities (Dersim, Maraş, Çorum, etc.) immediately after mentioning the "official elimination" of Armenians. The cities become emblems of those episodes of violence and they appear, in the speech, as echoes of the founding genocide of the republic. The speech offers a history of the Gezi protests that begins not with the ruling party and its belligerent leader, nor with the neoliberal turn in state policy, but with the constituting moment of the republic itself. It implicates the form of the body politic as such, including its "counterpart among the people," who have been empowered to speak as a sovereign nation.

The political party that Demirtaş represented was the most prominent voice in mainstream politics to speak on behalf of rights and freedoms for Kurds: cultural and linguistic rights (the right to use Kurdish in elementary schools, political campaigns, and courtrooms); rights for self-governance (in proposals to decentralize certain aspects of governance to provincial levels); and the granting of amnesty to political prisoners and releasing the leader of the PKK, Abdullah Öcalan, from solitary confinement. In this particular speech, Demirtaş was not primarily concerned with these issues, which are often glossed as the "Kurdish question," but with what we might call a Turkish question. ${ }^{10}$ He made an appeal to the putative majority not simply to question state violence, by for instance recognizing the killing of Armenians as a genocide. His was not a project aimed at redeeming the nation in a liberal vintage that is more inclusive and less authoritarian. The persistent dilemma with that kind of liberalism, in Turkey as elsewhere, is that it remains premised on the perspective of the majority, which can then offer or withhold tolerance to the marginalized (Brown 2006). The often unacknowledged statist commitments of that sort of liberalism reinforce, rather than scrutinize, the split between the progressive historicity of the nation and the 
negative historicity of the minority. Demirtaş's demand went further, admonishing the would-be majority for failing to push the critique of violence to the point where it implicates its own constitution as an ethnic majority. He summoned those who would see themselves as part of the Turkish majority to develop a critique of violence that not only condemns the ruling government but one that leads to a self-transformation, where it might question the very aspiration to majority status.

\section{A POLEMICAL ETHICS}

We have witnessed a flurry of debates about political futures after Gezi, much of which have centered on how the oppositional spirit of the protest might be preserved or harnessed after its conclusion. Would the uprisings yield electoral consequences damaging to the ruling party? What alternate forms of politics, aside from the ballot box, could be developed to reactivate its energy and its collaborative ethos? Or, scaling up, in what ways were the protests contributing to a global movement of resistance connected to anti-austerity protests in southern Europe, the Occupy movement in North America, or the protests around public transportation in Brazil, to name just a few (see Tuğal 2013)? The materials I have been examining in this essay permit us to remain sensitive to the temporal conditions of possibility for such debates: whose experience matters and to which political future?

The Gezi Park protests could, for instance, be interpreted as a relatively spontaneous uprising against the ruling government, its increasing controls on public sociability, its embrace of neoliberal politico-economic measures, and its intensifying hostility toward political opponents. But if, following the Saturday Mothers, we view the police actions in Gezi Park as continuous with a space of experience that includes the enforced disappearances in the 1980s and 1990s, then how would the target of the critique shift and where would the burden of responsibility for violence fall? In what ways would some of the protesters themselves, including especially those who identify as members of the Turkish majority, be implicated in the tradition of state violence being renewed by the government today? If, following Demirtaş, we wrote the history of the Gezi uprisings by beginning with the foundational violence of the Armenian genocide, how would that alter the horizon of expectation emerging from the current protests?

There is an ethical contentiousness to these questions that would be elided if, with Ernesto Laclau (2005), we rushed to discern the chains of equivalence emerging between different social and political communities. That sort of theo- 
rization could offer a plausible explanation of the pluralistic character of the protests, in which a wide variety of otherwise distinct, sometimes rival, political communities contingently articulated their disparate demands with one another, under the sign of Gezi Park and against the ruling government. ${ }^{11} \mathrm{I}$ am not, however, convinced that, when the Mothers and Demirtaş drew comparisons between historical events of state violence and the current confrontations with police brutality, their aim was simply to help develop a popular bloc of opposition. Rather than investing in the signifier of Gezi Park, their queries interrogated the ethical demands that an emergent political connection should make on the majority - of its responsiveness to forms of political identification that the state has long labeled as terrorism, and its willingness to claim responsibility for acts of violence committed by the state in its name.

Judith Butler $(2009$, 36) takes us somewhat closer to the matter at hand by outlining a notion of political obligation in terms of shared vulnerability to violence. She not only moves away from historically resonant notions of substantive (ethnic, religious, linguistic) unity but calls for a conception of political relationality that arises precisely when more conventionally nationalist notions of identification are put into question: "What is our responsibility . . . toward those who seem to test our sense of belonging or to defy available norms of likeness?" The commentaries that I have discussed largely avoid drawing on the worn tropes of national indivisibility as the ground of political unity. Instead, they highlight the increasing impossibility for those in the would-be majority to escape the violent address of security forces. State violence is not just under indictment; it leaves in its wake the terrain on which a new political community might be identified.

Certain moments of protest during the Gezi events in fact sought to build new forms of political connection on the basis of a shared vulnerability to the ongoing violence. After Medeni Yıldırım, an eighteen-year-old Kurd, was killed in the largely Kurdish town of Lice while protesting the building of a military outpost, Gezi protesters in Istanbul, Ankara, and elsewhere began to incorporate Yıldırım and Lice into their slogans. Protesters in Kadıköy, a neighborhood of Istanbul known for its middle-class, secular-nationalist Turkish inhabitants, were reportedly chanting the Kurdish phrase Bijî biratiya gelan ("Long live the brotherhood of the peoples"), as well as a Turkish-language slogan of solidarity, Diren Lice, Kadıköy seninle ("Resist Lice, Kadıköy is with you”) (Schafers and İlengiz 2013). As a term meant to promote solidarity, brotherhood may be irreparably compromised by the patriarchal ethnonationalism that has defined its dominant usage. However, its invocation in Kurdish and its coupling with a pluralized 
"peoples" suggest that critical labor is being performed on the concept itself. In a context where the public use of Kurdish has been banned, censored, and discouraged, and where political officials have been accused of aiding terrorism because of their choice of linguistic code (see Jamison, forthcoming), these gestures evince a sense of responsibility toward those who unsettle "available norms of likeness."

These assertions of solidarity claim a shared vulnerability, in Butler's sense, but the question that remains open to dispute is how any such claim indexes an anticipated future. The commentaries I have examined in this essay point to common encounters with state violence, but they also lay bare the historically unequal distribution of that violence. They harbor a polemical ethics whose force derives from the way they recast the temporal valence of the minority. Confrontational rather than conciliatory, Demirtaş and the Mothers' respective discourses convey an ethical charge because they ask the majority to see its own horizon of expectation defined anew, not in relation to the privileged past of the nation, but through an experience of state violence more commonly reserved for the minority. Demirtaş and the Mothers do not present the negative historicity of the minority simply as an outrageous violation of the republic's highest ideals; that outrage stands as a precedent anticipating a political community to come. More than becoming sensitive to the plight of the minority, the would-be majority is asked to see the minority's past as prefiguring the form of its own political future.

If we were to discern in these critical discourses a nascent form of political community-in-the-making, we would have to begin with the unsettling, even paradoxical, notion that the subject of politics they project is formed on the basis of exclusions constitutive of "the people" in the republican state. This vexed reassessment of experience and expectation suggests that the oppressed minority stands as a model for the political identification of the majority. Perhaps we need a figure for political thought that, evoking the dialectical tensions that animate the materials presented here, would summon the ethnic and gendered politics of the nation-state - but only to mark their negation. A brotherhood in dispossession, let us say, which can even incorporate the dominant majority, but only to the degree that it too has faced the violence of the state as a precondition for its entry into politics.

\section{ABSTRACT}

The category of minority has been constitutive of the concept of the people in Turkey, distilling those who do not belong to the history and destiny of the nation from those 
who do. Minority, in this sense, is not simply a demographic classification, nor merely a matter of legal recognition. It carries the weight of a historical judgment, which scaffolds political community by delineating which populations, languages, and religions remain beyond the framework of collective obligation and responsibility. This essay examines comments delivered by a pro-Kurdish political party and a largely Kurdish mothers-of-the-disappeared group during Turkey's Gezi Park protests of 2013. These moments of public address participated in the broader spirit of state critique on display during those demonstrations. They were noteworthy, however, for recasting the Gezi events as a late occurrence in a longer history of state violence, prefigured by a century of dispossession experienced by those who have been classed as minorities or threatened with that designation. The essay asks how these invocations of history enabled interventions into imagined futures. The commentaries were not primarily aimed at repudiating the historical judgment of minority as discriminatory or contrary to law, but instead sought to delocalize the judgment vested in the category of minority, to see in that judgment an increasingly generalized economy of state violence, and to view it as prefiguring a political community to come. [futures; politics of history; ethics; protest; minorities]

\section{NOTES}

Acknowledgments This essay has greatly benefited from the criticisms of a number of friends and colleagues. I am especially grateful to Joseph Hankins, Kelda Jamison, Banu Karaca, and Sarah Muir, who generously read multiple drafts. I also thank Faiz Ahmed, Yeşim Arat, Elif Babül, Frrat Bozçalı, Zeynep Gülru Göker, Heiko Henkel, Cemal Kafadar, David Nugent, Esra Özyürek, Öykü Potuoğlu-Cook, Joan Scott, Kamala Visweswaran, and Jarrett Zigon for their comments on the essay. Sertaç Kaya Şen provided crucial research assistance. I presented earlier versions of this essay at Boston University, Harvard University, Brown University, the London School of Economics, the University of Copenhagen, the University of Amsterdam, Koç University, Sabancı University, and Stanford University. I thank the organizers and participants at those events for their feedback. The editors and anonymous reviewers for Cultural Anthropology provided stimulating engagement that helped me develop the arguments. Research funding was provided by the Institute for Research in the Social Sciences and the Hellman Fellows Fund, both through Stanford University.

1. The Partiya Karkerên Kurdistan (PKK) is a Kurdish organization that has engaged in armed struggle against the Turkish state for more than three decades.

2. Not all participants in the protest had previously been uncritical of the Turkish state's use of force in Kurdish-majority regions. Some hailed from political communities long critical of the state, including some leftists, Alevis, Kurds, feminists, and anticapitalist Muslims. For one breakdown of class positions and political identities among the protestors, see Yörük and Yüksel 2014.

3. In their analysis of Erdoğan's populism, S. Erdem Aytaç and Ziya Öniş (2014, 45) excerpt an apposite quotation from one of his speeches: "My story is the story of this people. Either the people will win and come to power, or the pretentious and oppressive minority - estranged from the reality of Anatolia and looking over it with disdainwill remain in power."

4. The Saturday Mothers saw Argentina's Madres de Plaza de Mayo as a model to follow. On the similarities and differences between the two groups, see Baydar and İvegen 2006.

5. Other Saturday Mothers groups organize activities in a number of provinces in Turkey, 
especially in the Kurdish-majority southeast, where many of the disappearances took place.

6. Police harassment of the Mothers' gatherings spiked in 1998 and 1999. On the twohundredth week, the group suspended the vigils. At that point, 431 people had been arrested, with some held in custody for up to five days, and 40 participants were put on trial (Göker 2011b, 114).

7. Compare Joan Scott's (1996) analysis of the ways in which key French feminists avowed, even as they sought to undermine, tropes of sexual difference.

8. Irfan Aktan (2013) argues that the very questioning of the Kurds' presence in the protest resulted from and helped reinforce a political framework supported by Turkish nationalists.

9. On the hesitance, even resentment, felt by many Kurds toward the Gezi protests, see also Bozçalı and Yoltar 2013.

10. To the extent that the so-called Kurdish question implicates the formation of the Turkish state and the policing of its material and imaginative boundaries, it is always already a "Turkish question” (Ozsoy 2013).

11. Images juxtaposing signs of Turkish and Kurdish nationalism became iconic of this collaborative pluralism. For instance, a frequently circulated photo showed a man holding a portrait of Mustafa Kemal posing with another protester, who was holding a banner that displayed Abdullah Öcalan.

\section{REFERENCES}

Aktan, İran

2013 “Gezi, Kürtlerin de parkıdır.” Bir+Bir, June 27. http://birdirbir.org/gezikurtlerin-de-parkidir.

Altınay, Ayşe Gül

2004 The Myth of the Military-Nation: Militarism, Gender, and Education in Turkey. New York: Palgrave Macmillan.

Amnesty International

2013 "Gezi Park Protests: Brutal Denial of the Right to Peaceful Assembly in Turkey." EUR 44/022/2013, October. http://www.amnestyusa.org/research/reports/ gezi-park-protests-brutal-denial-of-the-right-to-peaceful-assembly-in-turkey.

Arat, Yeşim

1999 “Democracy and Women in Turkey: In Defense of Liberalism." Social Politics 6, no. 3: 370-87. http://dx.doi.org/10.1093/sp/6.3.370.

Aytaç, S. Erdem, and Ziya Öniş

2014 "Varieties of Populism in a Changing Global Context: The Divergent Paths of Erdoğan and Kirchnerismo." Comparative Politics 47, no. 1: 41-59. http://dx. doi.org/10.2139/ssrn.2261178.

Bakhtin, Mikhail M.

1986 “The Problem of Speech Genres.” In Speech Genres and Other Late Essays, translated by Vern W. McGee, 60-102. Austin: University of Texas Press.

Bargu, Banu

2014 "Sovereignty as Erasure: Rethinking Enforced Disappearances." Qui Parle 23, no. 1: 35-75. http://dx.doi.org/10.5250/quiparle.23.1.0035.

Baydar, Gülsüm, and Berfin İvegen

2006 "Territories, Identities, and Thresholds: The Saturday Mothers Phenomenon in Istanbul.” Signs 31, no. 3: 689-715. http://dx.doi.org/10.1086/498986.

Bayır, Derya

2013 Minorities and Nationalism in Turkish Law. Surrey, U.K.: Ashgate.

Boyer, Dominic

2013 "Simply the Best: Parody and Political Sincerity in Iceland." American Ethnologist 40, no. 2: 276-87. http://dx.doi.org/10.1111/amet.12020. 
Bozçalı, Fırat, and Çağrı Yoltar

2013 “A Look at Gezi Park from Turkey's Kurdistan.” In “An Impromptu Uprising: Ethnographic Reflections on the Gezi Park Protests in Turkey," Hot Spots series edited by Umut Yıldırım and Yael Navaro-Yashin, Cultural Anthropology website, October 31. http://www.culanth.org/fieldsights/396-a-look-at-gezi-parkfrom-turkey-s-kurdistan.

Brink-Danan, Marcy

2011 Jewish Life in Twenty-First-Century Turkey: The Other Side of Tolerance. Bloomington: Indiana University Press.

Brown, Wendy

2006 Regulating Aversion: Tolerance in the Age of Identity and Empire. Princeton, N.J.: Princeton University Press.

Bryant, Rebecca

2012 "Partitions of Memory: Wounds and Witnessing in Cyprus." Comparative Studies in Society and History 54, no. 2: 332-60. http://dx.doi.org/10.1017/ S0010417512000060.

Butler, Judith

2009 Frames of War: When is Life Grievable? New York: Verso.

Cody, Francis

2011 "Publics and Politics." Annual Review of Anthropology 40: 37-52. http://dx. doi.org/10.1146/annurev-anthro-081309-145626.

Coronil, Fernando

2011 "The Future in Question: History and Utopia in Latin America (1989-2010).” In Business as Usual: The Roots of the Global Financial Meltdown, edited by Craig

Demirtaş, Selahattin Calhoun and Georgi Derlugian, 213-64. New York: New York University Press.

2013 "BDP Grup Toplantısı." June 18. https://youtu.be/6WXaA7yaNd8.

Ekmekçioğlu, Lerna

2014 "Republic of Paradox: The League of Nations Minority Protection Regime and the New Turkey's Step-Citizens.” International Journal of Middle East Studies 46, no. 4: 657-79. http://dx.doi.org/10.1017/S0020743814001007.

Faubion, James D.

2011 An Anthropology of Ethics. Cambridge: Cambridge University Press.

Ferguson, James

1999 Expectations of Modernity: Myths and Meanings of Urban Life on the Zambian Copperbelt. Berkeley: University of California Press.

Göker, Zeynep Gülru

2011 a "The Politics of Silence: Discussing Deliberative and Agonistic Democracy visà-vis Gendered Responses to the Militarization of Everyday Life in Turkey.” PhD dissertation, City University of New York.

2011 b "Presence in Silence: Feminist and Democratic Implications of the Saturday Vigils in Turkey." In Social Movements, Mobilization, and Contestation in the Middle East and North Africa, edited by Joel Beinin and Frédéric Vairel, 107-24. Stanford, Calif.: Stanford University Press.

Haugerud, Angelique

2012 "Satire and Dissent in the Age of Billionaires." Social Research 79, no. 1: 145-

Jakobson, Roman 68. http://dx.doi.org/10.1353/sor.2012.0018.

1960 “Closing Statement: Linguistics and Poetics." In Style in Language, edited by Jamison, Kelda Thomas A. Sebeok, 350-77. Cambridge, Mass.: MIT Press.

Forthcoming "Hefty Dictionaries in Incomprehensible Tongues: Commensurating Code and Language Community in Turkey." Anthropological Quarterly. 
Keane, Webb

2014 "Affordances and Reflexivity in Ethical Life: An Ethnographic Stance." Anthropological Theory 14, no. 1: 3-26. http://dx.doi.org/10.1177/ 1463499614521721.

Koselleck, Reinhart

2004 Futures Past: On the Semantics of Historical Time. Translated by Keith Tribe. New York: Columbia University Press.

Laclau, Ernesto

2005 On Populist Reason. New York: Verso.

Laidlaw, James

2014 The Subject of Virtue: An Anthropology of Ethics and Freedom. Cambridge: Cambridge University Press.

Mahmood, Saba

2005 Politics of Piety: The Islamic Revival and the Feminist Subject. Princeton, N.J.: Princeton University Press.

2012 "Religious Freedom, the Minority Question, and Geopolitics in the Middle East." Comparative Studies in Society and History 54, no. 2: 418-46. http://dx.doi.org/ 10.1017/S0010417512000096.

Makley, Charlene

2015 "The Sociopolitical Lives of Dead Bodies: Tibetan Self-Immolation Protest as Mass Media." Cultural Anthropology 30, no. 3: 448-76. http://dx.doi.org/ 10.14506/ca30.3.05.

Mazower, Mark

1997 "Minorities and the League of Nations in Interwar Europe." Daedalus 126, no. 2: 47-63. http://www.jstor.org/stable/20027428.

Mazzarella, William

2013 Censorium: Cinema and the Open Edge of Mass Publicity. Durham, N.C.: Duke University Press.

Muir, Sarah

2015 "The Currency of Failure: Money and Middle-Class Critique in Post-Crisis Buenos Aires." Cultural Anthropology 30, no. 2: 310-35. http://dx.doi.org/ 10.14506/ca30.2.10.

Navaro-Yashin, Yael

2002 Faces of the State: Secularism and Public Life in Turkey. Princeton, N.J.: Princeton University Press.

Özsoy, Hişyar

2013 "Introduction: The Kurds' Ordeal with Turkey in a Transforming Middle East." Dialectical Anthropology 37, no. 1: 103-11. http://dx.doi.org/10.1007/s10624013-9297-y.

Özyürek, Esra

2009 "Christian and Turkish: Secularist Fears of a Converted Nation." Comparative Studies of South Asia, Africa, and the Middle East 29, no. 3: 398-412. http://dx.

Paker, Evren Balta doi.org/10.1215/1089201X-2009-027.

2010 “Dış Tehditten İç Tehdide: Türkiye' de Doksanlarda Ulusal Güvenliğin Yeniden Inşası.” In Türkiye’de Ordu, Devlet ve Güvenlik Siyaseti, edited by Evren Balta Paker Pandey, Gyanendra and İsmet Akça, 407-31. Istanbul: Bilgi Üniversitesi Yayınları.

1999 “Can a Muslim Be an Indian?" Comparative Studies in Society and History 41, no. 4: 608-29. http: / /www.jstor.org/stable/179423.

Parla, Ayşe

2011 "Labor Migration, Ethnic Kinship, and the Conundrum of Citizenship in Turkey."

Citizenship Studies 15, nos. 3-4: 457-70. http://dx.doi.org/10.1080/ 13621025.2011 .564809 . 
Piot, Charles

2010 Nostalgia for the Future: West Africa after the Cold War. Chicago: University of

Robbins, Joel Chicago Press.

2004 Becoming Sinners: Christianity and Moral Torment in a Papua New Guinea Society. Robinson, Shira Berkeley: University of California Press.

2013 Citizen Strangers: Palestinians and the Birth of Israel's Liberal Settler State. Stanford, Calif.: Stanford University Press.

Rodrigue, Aron

2013 "Reflections on Millets and Minorities: Ottoman Legacies." In Turkey Between Nationalism and Globalization, edited by Riva Kastoryano, 36-46. New York: Routledge.

Sabah

2013 “Başbakan Erdoğan Kazlıçeşme'de Konuştu.” June 16. http://www.sabah. com.tr/gundem/2013/6/16/basbakan-erdogan-kazlicesmede-konusuyor.

Schafers, Marlene, and Çiçek Ilengiz

2013 “Improbable Encounters: Marching for Lice in Kadıköy." In "An Impromptu Uprising: Ethnographic Reflections on the Gezi Park Protests in Turkey." Hot Spots series edited by Umut Yıldırım and Yael Navaro-Yashin, Cultural Anthropology website, October 31. http://www.culanth.org/fieldsights/404improbable-encounters-marching-for-lice-in-kadikoy.

Scott, Joan W.

1996 Only Paradoxes to Offer: French Feminists and the Rights of Man. Cambridge, Mass.: Tambar, Kabir Harvard University Press.

2012 “Islamic Reflexivity and the Uncritical Subject.” Journal of the Royal Anthropological Institute 18, no. 3: 652-72. http://dx.doi.org/10.1111/j.1467-9655.2012. 01781.x.

2014 The Reckoning of Pluralism: Political Belonging and the Demands of History in Turkey. Stanford, Calif.: Stanford University Press.

Tuğal, Cihan

2013 “'Resistance Everywhere': The Gezi Revolt in Global Perspective." New Perspectives on Turkey 49: 157-72. http://dx.doi.org/10.1017/ S0896634600002077.

Türk Tabipleri Birliği

2013 "Göstericilerin sağlık durumları/The Health Status of the Demonstrators." Weitz, Eric D.

August 1. http://www.ttb.org.tr/index.php/Haberler/veri-3944.html.

2008 "From the Vienna to the Paris System: International Politics and the Entangled Histories of Human Rights, Forced Deportations, and Civilizing Missions." American Historical Review 113, no. 5: 1313-43. http://dx.doi.org/10.1086/ ahr.113.5.1313.

White, Jenny

2013 Muslim Nationalism and the New Turks. Princeton, N.J.: Princeton University Press.

Yeğen, Mesut

2007 “'Jewish-Kurds' or the New Frontiers of Turkishness.” Patterns of Prejudice 41, no. 1: 1-20. http://dx.doi.org/10.1080/00313220601118736.

Yörük, Erdem, and Murat Yüksel

2014 “Class and Politics in Turkey's Gezi Protests.” New Left Review 89: 103-23. http: / / newleftreview.org/II/89/erdem-yoruk-murat-yuksel-class-and-politicsin-turkey-s-gezi-protests. 
Yurchak, Alexei

2008 "Necro-Utopia: The Politics of Indistinction and the Aesthetics of the NonSoviet." Current Anthropology 49, no. 2: 199-224. http://dx.doi.org/10.1086/ 526098.

Zigon, Jarrett

2007 "Moral Breakdown and the Ethical Demand: A Theoretical Framework for an Anthropology of Moralities." Anthropological Theory 7, no. 2: 131-50. http:// dx.doi.org/10.1177/1463499607077295. 